\title{
Kurikulum Dan Pendidikan Di Indonesia: Proses Mencari Arah Pendidikan Yang Ideal Di Indonesia Atau Hegemoni Kepentingan Penguasa Semata?
}

\author{
Oleh
}

\section{Dedi Ilham Perdana ${ }^{1}$}

\begin{abstract}
Abstrak
Abstract

Artikel ini bertujuan untuk menguak bagaimana problematika perubahan kurikulum dan pendidikan yang terjadi di Indonesia dari masa ke masa serta pengaruhnya pada masyarakat sekaligus memetakan berbagai isu terkait kurikulum baru 2013 serta dampaknya bagi dunia pendidikan saat ini. Hegemoni yang dilakukan pemerintah terkait perubahan kurikulum 2013 akan menjadi isu sentral dalam artikel ini sekaligus menganalisanya melalui pemikiran Antonio Gramsci.
\end{abstract}

Kata kunci: kebijakan pendidikan, perubahan kurikulum, kurikulum 2013, hegemoni

\begin{abstract}
This purpose of the article is to uncover the problematic changes that happens in the curriculum and education in Indonesia and its impact on society, as well as mapping various issues related to new curriculum 2013 and its implications for recent education. Hegemony conducted by government related to 2013 curriculum will be the central issue in this article, the author will analyzed using Antonio Gramsci is concept of hegemony.
\end{abstract}

Keywords: educational policy, curriculum change, curriculum 2013, hegemony

\section{A. Pendahuluan}

Masyarakat Indonesia telah sejak lama mengenal tentang kurikulum dan sangat fasih dengan berbagai perubahan yang telah dialami oleh kurikulum itu sendiri. Masyarakat awam di Indonesia juga telah mengenal istilah CBSA (cara belajar siswa aktif),
KBK (kurikulum berbasis kompetensi), serta KTSP (kurikulum tingkat satuan pendidikan) bahkan saat ini muncul kurikulum 2013 yang sudah mulai bergulir di beberapa sekolah baik negeri maupun swasta sekitar 6400-an sekolah yang sudah menjalankan kurikulum baru tersebut, tutur

\footnotetext{
${ }^{1}$ Dedi Ilham Perdana adalah alumni program pascasarjana Sosiologi UGM dan peneliti independen yang menaruh minat pada isu ketenagakerjaan dan pendidikan.
} 
Jurnal Pemikiran Sosiologi Volume 2 No. 1, 2013

Kurikulum Dan Pendidikan Di Indonesia:

Proses Mencari Arah Pendidikan Yang Ideal Di Indonesia Atau Hegemoni Kepentingan Penguasa Semata?

Dedi Ilham Perdana

Menteri Pendidikan dan Kebudayaan, Muhammad Nuh (Ella, 2013), sehingga seringkali muncul anggapan dari beberapa pihak anekdot berupa ganti menteri, ganti kurikulum seperti yang dilontarkan oleh pemerhati pendidikan dari Universitas Gajah Mada (UGM) Slamet Sutrisno, bahwa tiap ada pergantian menteri selalu membawa paket baru dalam masa kepemimpinannya (Maf, 2013). Sentimen tersebut semakin memperkuat argumen masyarakat bahwa tiap kali ada pergantian kabinet selalu memunculkan polemik baru di kalangan insan pendidikan dan masyarakat umum, selalu terjadi transisi budaya yang dibawa tiap kali ada perubahan kurikulum yang dilakukan oleh pemerintah yang menjabat saat itu.

Situasi ini selalu menjadi problematika tersendiri bagi pelaku pendidikan di dalamnya yang terkait dengan perubahan setiap kurikulum yang terjadi, elemen seperti guru dan siswa contohnya, menjadi korban akan perubahan tersebut. Ritus yang selalu terjadi tatkala ada pergantian kurikulum ternyata membawa dampak sistemik pada gairah pembelajaran di Indonesia. Dari beberapa kasus perubahan kurikulum yang tersaji di Indonesia dalam beberapa dekade ini, terlihat adanya ketidakpuasan dari berbagai pihak, beban siswa dan beban guru yang menjadi bagian instrumen pendidikan merasakan bagaimana kebijakan perubahan kurikulum tersebut tersaji di hadapan mereka saat ini. Romo Benny Susetyo menjelaskan bahwa ada beban tersendiri bagi siswa dan guru apabila muncul kurikulum terbaru di tahun 2013, menurutnya perubahan kurikulum kali ini justru akan menambah beban peserta didik. Pasalnya, integrasi mata pelajaran dengan tema atau mata pelajaran lain ini membuat materi yang diajarkan menjadi bias sehingga butuh penjelasan lebih lanjut. (Damanik, 2013).

Polemik ini semakin bergulir panas ditengah kecemasan masyarakat bahwa akan terjadi perombakan besar dalam metode belajar dan nantinya hasil yang dicapai akan sama saja seperti tahun-tahun sebelumnya. Dibutuhkan sosialisasi khusus dalam hal pembaruan kurikulum, agar sasaran yang akan dicapai juga jelas (Allen, 2006). Seperti kecemasan Federasi Serikat Guru Indonesia (FSGI), menurut FSGI, rendahnya kualitas pengetahuan instruktur nasional sebagai pelatih inti guru-guru yang dipersiapkan menjalankan kurikulum 2013 akan menjadi batu sandungan ketika kurikulum baru tersebut harus dijalankan di sebuah institusi pendidikan (Fat, 2013). Produktifitas dan kinerja guru masih dibawah ratarata negara ASEAN, bahkan menurut indeks saat ini Indonesia masih tertinggal dari Brunei Darussalam yang berada di peringkat ke-34. Brunei Darussalam masuk kelompok pencapaian tinggi bersama Jepang, yang mencapai posisi nomor satu Asia. Adapun Malaysia berada di peringkat ke-65 atau masih dalam kategori kelompok pencapaian medium seperti halnya Indonesia. Meskipun demikian posisi Indonesia saat ini masih jauh lebih baik dari Filipina (85), Kamboja (102), India (107), dan Laos (109). Hal ini sangat kontraproduktif dengan kemauan pemerintah untuk melakukan implementasi kebijakan perubahan kurikulum 2013 yang sengaja ditujukan untuk meningkatkan daya saing siswa dengan siswa yang berada di luar negeri . Tentunya harus dilihat secara mendalam, pernyataan Menteri Nuh terkait wacana kurikulum 2013 untuk mengejar 
Jurnal Pemikiran Sosiologi Volume 2 No. 1, 2013

Kurikulum Dan Pendidikan Di Indonesia:

Proses Mencari Arah Pendidikan Yang Ideal Di Indonesia Atau Hegemoni Kepentingan Penguasa Semata?

Dedi Ilham Perdana

ketertinggalan dengan negara tetangga, dengan ketidakmerataan fasilitas pendidikan di daerahdaerah, nampaknya hal tersebut sangat mungkin untuk ditolak, karena memang jika mengacu pada kecemasan FPGI diatas, tentunya kurikulum 2013 tidak bisa dijalankan dengan baik oleh elemen pendidikan di Indonesia secara luas hanya sebagian daerah saja yang siap yang tentunya fasilitas penunjang kurikulum memadai pula.

Perlu dicermati bersama bahwa perubahan kurikulum tentunya mengarah pada keberadaan pihak ketiga yang melatar-belakangi adanya perubahan kurikulum agar tujuan ekonomis berjalan lancar dan pengatasnamaan pendidikan untuk memajukan bangsa dapat menjadi jargon ampuh dalam setiap tindakan pengambilan keputusan perubahan kurikulum. Eko Prasetyo menjelaskan bahwa pendidikan di Indonesia yang selalu berganti-ganti arah (diwujudkan dengan pergantian kurikulum) hanya menguntungkan segelintir pihak saja, yakni penguasa saat itu, korporasi dan pihak luar negeri melalui Bank Dunia (Prasetyo, 2006), selain itu Kompas memberitakan kebocoran dana pada pihak seperti penerbit buku akan menjadi taruhan lain dari perubahan kurikulum yang terjadi di Indonesia (dalam Prasetyo, 2006). Fenomena tersebut akan terus terjadi apabila tidak ada komitmen dan landasan berpikir yang jelas tentang arah futuristik model pendidikan di Indonesia.

\section{B. Mengenal Kurikulum dan Pendidikan di Indonesia}

Malcolm Skillbeck (dalam Print, 1993) mengatakan bahwa;

"Curriculum will be used to refer to the learning experiences of students, in so far as they are expressed on anticipated in goal and objectives, plans and design for learning and the implementation of these plans and design in school environments."

Dalam hal ini menurut Skillbeck, kurikulum digunakan untuk acuan pengalaman pembelajaran siswa, diperlihatkan dalam pembentukan tujuan, rencana, dan rancangan untuk pembelajaran dan pengimplementasian dari rencana-rencana tersebut dan rancangan dalam lingkungan sekolah. Sementara Nasution menjelaskan bahwa kurikulum adalah suatu rencana yang disusun untuk melancarkan proses belajar-mengajar di bawah bimbingan dan tanggung-jawab sekolah atau lembaga pendidikan besrta staf pengajarnya.

Dari definisi kurikulum diatas, kurikulum berarti sebuah cara yang dipilih untuk memantapkan model pembelajaran untuk proses belajar dan mengajar, tentunya cara yang disebutkan harus punya landasan yang sesuai dengan kepribadian suatu budaya contohnya dalam konteks Indonesia, kurikulum harus memperhatikan kebutuhan mendasar dari masyarakat yang akan mengkonsumsi pendidikan sesuai amanat UndangUndang Dasar 1945. Pendidikan sesungguhnya salah satu cara paling pokok dalam memajukan 
Jurnal Pemikiran Sosiologi Volume 2 No. 1, 2013

Kurikulum Dan Pendidikan Di Indonesia:

Proses Mencari Arah Pendidikan Yang Ideal Di Indonesia Atau Hegemoni Kepentingan Penguasa Semata?

Dedi Ilham Perdana

generasi sehingga pantaslah dalam Pembukaan UUD 1945 termaktub dengan tegas menyebutkan:

1. Mengamanatkan pemerintah negara Indonesia yang melindungi segenap bangsa Indonesia dan seluruh tumpah darah Indonesia dan untuk memajukan kesejahteraan umum, mencerdaskan kehidupan bangsa, dan ikut melaksanakan ketertiban dunia yang berdasarkan kemerdekaan, perdamaian abadi dan keadilan sosial.

2. Mengamanatkan pemerintah mengusahakan dan menyelenggarakan satu sistem pendidikan nasional yang meningkatkan keimanan dan ketakwaan kepada Tuhan Yang Maha Esa serta akhlak mulia dalam rangka mencerdaskan kehidupan bangsa yang diatur dengan undangundang.

3. Bahwa sistem pendidikan nasional harus mampu menjamin pemerataan kesempatan pendidikan, peningkatan mutu serta relevansi dan efisiensi manajemen pendidikan untuk menghadapi tantangan sesuai dengan tuntutan perubahan kehidupan lokal, nasional, dan global sehingga perlu dilakukan pembaharuan pendidikan secara terencana, terarah, dan berkesinambungan.

Demikian tegasnya Amanat UUD 1945 itu sehingga kita juga patut mempertanyakan hingga dimana kewajiban itu ditaati dan dilaksanakan Pemerintah. Pertanyaan itu tentu saja timbul karena didorong oleh fakta yang sangat memperihatinkan termasuk soal mahalnya biaya pendidikan dan tidak adanya jaminan tentang keberhasilan pendidikan yang diselenggarakan dalam mengubah keadaan hidup seseorang secara lebih baik ketimbang sebelumnya.
Pendidikan yang terselenggarakan ternyata sangat tidak adil atau diskriminatif, lihat saja sekolahsekolah atau lembaga pendidikan yang diselenggarakan dilokasi pinggiran kota apalagi pedesaan. Padahal mereka yang didesa dan dikota sama kedudukannya dimata UUD 1945 atas nama Warga Negara. Seharusnya justru mereka yang tinggal dipinggiran kota dan pedesaan itu menjadi fokus mengingat mereka hidup dalam kategoti ekonomi yang tidak berdaya.

Kalaupun ada ternyata sekolah-sekolah atau lembaga Pendidikan yang dibangun dipinggiran kota dan pedesaan itu malah menjadi semacam menara gading yang sedap dipandang mata namun tidak terjangkau, hanya menjadi khayalan bagi anakanak desa itu. Problemanya disitu, sekolah-sekolah yang berada didesa-desa itu sama kumuhnya dengan kehidupan masyarakat pedesaan. Seolaholah kondisi itu adalah ciri khas dari ideologi pendidikan Nasional kita sehingga akhirnya banyak orang yang menghalalkan idiom pendidikan itu mahal, kalau mau bermutu ya bayar mahal. Rakyat yang kurang beruntung terperangkap ke dalam penjara kemiskinan struktural. Pemerataan pendidikan tidak cukup diartikan hanya membangun gedung-gedung sekolah standar saja, tanpa memperhatikan kelengkapan fasilitas yang mendukung tercapainya misi pendidikan dalam merubah kehidupan yang lebih baik dibandingkan sebelumnya.

Kebijaksanaan dalam pelaksanaan program pendidikan harus seutuhnya menyentuh persoalan kemanusiaan yang tidak bersifat diskriminatif dari sudut manapun juga. Pendidikan mestinya mampu menjawab semua persoalan hidup masyarakat, baik 
Jurnal Pemikiran Sosiologi Volume 2 No. 1, 2013

Kurikulum Dan Pendidikan Di Indonesia:

Proses Mencari Arah Pendidikan Yang Ideal Di Indonesia Atau Hegemoni Kepentingan Penguasa Semata?

Dedi Ilham Perdana

ekonomi, sosial, budaya dan karakter. Jika masyarakat yang miskin lebih banyak dibanding masyarakat yang kaya maka jelas program pendidikan kita tidak berhasil. Program pendidikan yang dimaksud tidak hanya sekedar soal beasiswa, soal gedung, soal BOS, soal gelar tetapi menyeluruh termasuk jaminan pendidikan terhadap hasil kehidupan yang jauh lebih makmur.

\section{Problematika Pendidikan di Indonesia}

Pesimisme berbagai pihak terkait arah pendidikan saat ini, ternyata tak mampu untuk merubah kemantapan hati pemerintah untuk tetap menjalankan kurikulum yang belum tentu bisa diterima oleh semua kalangan di Indonesia. kurikulum saat ini berupaya mengarahkan siswa untuk menuju kapitalisasi pendidikan, problematika pendidikan di Indonesia menjadi sangat tersimpilifikasi menjadi hanya permasalahan kurikulum, dan bukan hanya polemik terkait kemampuan adaptif manusia Indonesia, latar belakang sosial para murid, dan seabrek permasalahan yang sistemik yang justru lebih urgent untuk dipahami oleh pemangku kepentingan pendidikan. Kelompok elite di dunia pendidikan Indonesia merasa yang paling berkepentingan terhadap pendidikan, mencoba untuk merepresentasi pemikirannya menjadi pembentuk wacana publik atas kepentingan penguasa saja (McLaren, 2000). Dalam artian ini, McLaren menjelaskan bahwa kelas penguasa, lebih memiliki ruang gerak bebas untuk mengarahkan arah pendidikan di Indonesia ke depan bagaimana, karena kelas penguasa, punya sarana untuk menguasai wacana publik di masyarakat.
Upaya mendorong wacana publik dari kelas penguasa telah hadir ditengah masyarakat melalui kurikulum yang ada. Seperti yang dijelaskan Niels Mulder bahwa ada upaya mengarahkan wacana publik massa di Indonesia dengan serangkaian tematik tentang bagaimana seharusnya bersikap seperti manusia di Indonesia. Dalam hal ini, dia mencontohkan bagaimana kekerasan simbolis yang sah, dimana pelajaran wajib ilmu pengetahuan sosial untuk kelas tiga sampai kelas enam bertujuan menanamkan pengetahuan dasar dan ketrampilan yang akan berguna bagi siswa di kehidupan seharihari (Mulder, 2007). Dalam segi ini, mata pelajaran di Indonesia telah dicetak dengan kepentingan untuk mendisiplinkan karakter dari masyarakat Indonesia sehingga mampu membantu penguasa yang ada di Indonesia untuk mewujudkan keinginan dari kepribadian penguasa lewat teks bacaan semenjak sekolah dasar. Mulder menjelaskan bahwa, memang ideologi nasional lambat laun akan diajarkan secara lebih baik ketika kelas yang dicapai semakin tinggi, yang artinya semakin seorang murid naik kelas, maka dia akan mendapatkan penjelasan yang konkret bagaimana sebagai warga negara dia harus bertindak. Sebagai contoh, pada saat pelajaran kelas tiga SD akan diajarkan bagaimana seorang keluarga memiliki ayah dan ibu, ayah bekerja di luar rumah, sedangkan ibu bekerja di wilayah domestik rumah, semakin menanjak pada kelas empat SD, kita menemukan bahwa semakin menarik topik bahasan yang ditemukan, dimana ada pembelajaran tentang koordinat dan peta yang mengajarkan letak dan psosisi geografis Indonesia secara jelas, menginjak pada kelas lima SD, kita melihat biasnya pembelajaran metodis digantikan dengan ideologi 
Jurnal Pemikiran Sosiologi Volume 2 No. 1, 2013

Kurikulum Dan Pendidikan Di Indonesia:

Proses Mencari Arah Pendidikan Yang Ideal Di Indonesia Atau Hegemoni Kepentingan Penguasa Semata?

Dedi Ilham Perdana

nasional yang dibarengi dengan sejarah pergerakn bangsa (Mulder, 2007).

Tentunya dari pelbagai kasus tentang pelajaran di Indonesia hanya mengarah pada kelas penguasa yang ingin menanamkan kepatuhan pada generasi mudanya sehingga buta akan sejarah yang sebenanya terjadi di Indonesia, dan tentunya akan membutakan semua generasi yang akan lahir di bumi Indonesia ke depan. Eko Prasetyo menjelaskan tentang kaitannya pelajaran sejarah di buku teks pelajaran di Indonesia rentan akan kaburnya makna nyata sejarah itu sendiri, pelajaran yang ada di sejarah terlalu membahas tentang mistisisme dan legenda daripada mengajarkan tentang teori dan landasan berpikir, alih-alih bercerita tentang faktual sejarah, malahan lebih menitikberatkan pada kekayaan dongeng masa lalu (Prasetyo, 2006).

Kurikulum diciptakan untuk menjadi sarana perubahan masyarakat menjadi lebih baik, dengan mengesampingkan banyaknya masalah yang ada di dalam masyarakat itu sendiri, dan masyarakat menganggap itu sebagai norma yang wajar. McLaren, sebagaimana yang dikutip Barton (dalam Nuryatno, 2001), mengemukakan tiga dampak kapitalisme terhadap pendidikan:

1. Hubungan antara kapitalisme dan pendidikan urban telah menyebabkan praktek-praktek sekolah yang lebih mendukung kontrol ekonomi oleh kelaskelas elit.

2. Hubungan antara kapitalisme dan ilmu pengetahuan telah mendorong berkembangnya ilmu pengetahuan yang hanya bertujuan mendapatkan profit material dibanding untuk menciptakan kehidupan global yang lebih baik.
3. Perkawinan antara kapitalisme dan pendidikan dan kapitalisme dan ilmu pengetahuan telah menciptakan fondasi bagi ilmu pendidikan yang menekankan nilai-nilai korporasi dengan mengorbankan nilai-nilai keadilan sosial dan martabat kemanusiaan.

Kompleksitas pendidikan di Indonesia menjadi lahan empuk bagi sebagian pihak untuk mewacanakan adanya perubahan kurikulum 2013 menjadi obat bagi sistem pendidikan di Indonesia saat ini. Pendidik serta murid menjadi sarana malpraktekakan hal ini. Belum tuntas wacana tentang sertifikasi guru, muncul masalah dengan adanya ujian nasional dan kesalahan cetak buku penunjang bagi siswa.

Adanya konvensi ujian nasional, menyiratkan banyak pihak, bahwa konvensi ujian nasional sebagai alat legitimasi pihak yang terkait dengan ujian nasional agar bisa merangkul semua pihak yang tak sepaham dengan wacana bergulirnya ujian nasional, alih-alih mengakomodir tuntutan banyak pihak yang memprotesnya, konvensi tersebut dijadikan sebagai ajang merumuskan kebijakan ujian nasional ke depan. Sejumlah guru dan pegiat pendidikan yang tergabung dalam Koalisi Reformasi Pendidikan mengambil langkah ekstrim saat pembukaan Konvensi Ujian Nasional yang digelar Kementerian Pendidikan Nasional.

Menurut Retno Listyarti, pelaksanaan Ujian Nasional sangat dipaksakan oleh pemerintah. UN juga dinilai gagal mewujudkan kesetaraan kualitas pendidikan seperti yang disampaikan. Ujian Nasional justru dinilai menjadi ajang pembodohan bagi siswa. Koalisi kata Retno menilai, penilaian akhir terhadap kelulusan siswa seharusnya 
Jurnal Pemikiran Sosiologi Volume 2 No. 1, 2013

Kurikulum Dan Pendidikan Di Indonesia:

Proses Mencari Arah Pendidikan Yang Ideal Di Indonesia Atau Hegemoni Kepentingan Penguasa Semata?

Dedi Ilham Perdana

ditetapkan oleh sekolah dan bukan melalui standar angka-angka yang ditetapkan pemerintah. Sebelumnya koalisi berharap konvensi menjadi ajang konsensus bagi guru, dinas pendidikan, akademisi, dan pemerhati untuk merumuskan apakah UN bisa dilanjutkan atau tidak. Kenyataannya, konvensi hanya untuk menggiring peserta menyetujui pelaksanaan UN (Sufa, 2013). Lebih lanjut terkait pada fokus kurikulum 2013 di berbagai daerah, Federasi Serikat Guru Indonesia (FSGI) memantau pelatihan guru dan persiapan implementasi Kurikulum 2013 di 17 kabupaten/kota dari 10 provinsi di Tanah Air.

Hasilnya, kegagalan sistemik pelatihan guru dan sejumlah masalah krusial implementasi Kurikulum 2013 ditemukan. Pelatihan hanya berlangsung searah dan mengedepankan ceramah. FSGI menilai ini akan berdampak pada kegagalan mengubah paradigma guru dalam pembelajaran. Ini akan menjadi sumber kegagalan implementasi Kurikulum 2013. Harus diingat substansi perubahan dari Kurikulum 2006 ke 2013 adalah perubahan proses pembelajaran. Dari pola guru menulis di papan tulis lalu murid mencatat atau guru menerangkan murid mendengar menjadi pola yang mengedepankan murid pengamatan, bertanya, mencoba, dan mengeksplorasi. Pola itu hanya mungkin terwujud bila mindset guru telah berubah. Hal ini bukan perkara mudah. Mengubah mindset guru menjadi pekerjaan rumah untuk Kementerian Pendidikan dan Kebudayaan. Perubahan mindset guru tidak bisa dilakukan dalam waktu singkat, butuh waktu bertahun-tahun. Padahal Kurikulum 2013 akan dilaksanakan dalam waktu secepatnya. Perubahan itu dilakukan dengan mendorong guru untuk terus belajar. Dalam pelatihan guru, sekolah kesulitan menentukan guru yang akan pelatihan. Lantaran hanya satu hingga dua guru yang diminta.

Ketika guru bahasa Indonesia dan bahasa Inggris digabung, ternyata terjadi diskriminasi. Mulai dari tempat menginap sampai keterlambatan menerima soal pretest. Di Sumenep malah tidak terdengar hingar bingar Kurikulum 2013. Tidak ada sosialisasi dan penunjukkan sekolah yang menerapkan. Problem teknis, adanya pelajaran yang hilang dan bertambah jamnya sehingga membingungkan pihak sekolah karena berimplikasi pada nasib guru. Di antaranya penghapusan mata pelajaran Teknologi Informasi dan Komputer (TIK) di SMP dan SMA. Selain itu, dalam Kurikulum 2013 tidak ada pedoman penjurusan atau minat di tingkat SMA. Tidak ada pula sosialisasi kepada kepala program keahlian di SMK. Ini membingungkan pihak sekolah, guru, dan murid tentunya (Khaddaf, 2013).

Dengan banyaknya permasalahan tentang kurikulum dan hal terkait pendidikan di Indonesia, tentunya masyarakat Indonesia mempertanyakan arah kebijakan yang diambil oleh pemerintah, apakah untuk kalangan tertentu yang akan mengambil keuntungan atas kebijakan perubahan itu, atau memang untuk kemajuan di bidang pendidikan Indonesia? 
Jurnal Pemikiran Sosiologi Volume 2 No. 1, 2013

Kurikulum Dan Pendidikan Di Indonesia:

Proses Mencari Arah Pendidikan Yang Ideal Di Indonesia Atau Hegemoni Kepentingan Penguasa Semata?

Dedi Ilham Perdana

D. Membaca Arah Pendidikan di Indonesia di Kurikulum 2013: Hegemoni Pemerintah Terhadap Dunia Pendidikan

Seperti yang telah dijelaskan sebelumnya bahwa kurikulum 2013 mengedepankan integralisasi mata pelajaran dan tidak ada lagi model mata pelajaran yang terpisah-pisah, menjadikan guru mata pelajaran tertentu akan semakin kehilangan taji dalam mengajar, karena di tiap kesempatan mengajar, seorang guru mata pelajaran tertentu harus memasukkan unsur mata pelajaran yang lain ke dalam pelajaran yang akan diajarkannya, ini sangat bertentangan dengan paham dirinya selama ini. Sedikitnya ada enam perubahan yang terjadi pada kurikulum 2013 dengan kurikulum yang lama.

Pertama, terkait dengan penataan sistem perbukuan. Lazim berlaku selama ini buku ditentukan oleh penerbit baik terkait dengan isi. Menyangkut isi, karena keterbatasan wawasan dan kepekaan para penulis, kegaduhan terhadap isi buku pun sering terjadi. Kejadian terakhir di Kabupaten Bogor pada buku Pelajaran Bahasa Indonesia untuk kelas 6 SD (Cerita porno, dan lain sebagainya). Penataan sistem perbukuan dalam implementasi Kurikulum 2013 dikelola oleh Pusat Kurikulum dan Perbukuan dan substansinya diarahkan oleh tim pengarah dan pengembang kurikulum. Tujuannya agar isi dapat dikendalikan dan kualitas lebih baik. Selain itu, harga bisa ditekan lebih wajar. Kedua, penataan Lembaga Pendidik Tenaga Kependidikan (LPTK) di dalam penyiapan dan pengadaan guru. Ketiga, penataan terhadap pola pelatihan guru. Pengalaman pada pelaksanaan pelatihan instruktur nasional, guru inti, dan guru sasaran untuk implementasi Kurikulum 2013, misalnya, banyak pendekatan pelatihan yang harus disesuaikan, baik menyangkut materi pelatihan maupun model dan pola pelatihan. Momentum Kurikulum 2013 adalah hal yang tepat untuk melakukan penataan terhadap pola pelatihan guru termasuk penjenjangan terhadap karir guru dan kepangkatannya. Ke depan, sedang disiapkan konsep yang terintegrasi antara jenjang karier dan kepangkatan dengan penilaian profesi guru. Selama ini keduanya terpisah. Keempat, memperkuat budaya sekolah melalui pengintegrasian kurikuler, ko-kurikuler, dan ekstrakurikuler, serta penguatan peran guru bimbingan dan konseling (BK). Kelima, terkait dengan memperkuat NKRI. Melalui kegiatan ekstrakurikuler kepramukaan-lah, peserta didik diharapkan mendapat porsi tambahan pendidikan karakter, baik menyangkut nilai-nilai kebangsaan, keagamaan, toleransi dan lainnya. Keenam, ini juga masih terkait dengan hal kelima, memperkuat integrasi pengetahuan-bahasa-budaya. Pada Kurikulum 2013, peran bahasa Indonesia menjadi dominan, yaitu sebagai saluran mengantarkan kandungan materi dari semua sumber kompetensi kepada peserta didik, sehingga bahasa berkedudukan sebagai penghela mata pelajaranmata pelajaran lain. Kandungan materi pada pelajaran lain dijadikan sebagai konteks dalam penggunaan jenis teks yang sesuai dalam pelajaran bahasa Indonesia. Melalui cara ini, maka pembelajaran bahasa Indonesia termasuk kebudayaan dapat dibuat menjadi kontekstual. Sesuatu yang hilang pada model pembelajaran bahasa Indonesia saat ini. Dari efek domina itulah maka Kurikulum 2013 adalah bagian tidak terpisahkan untuk menata berbagai aspek 
Jurnal Pemikiran Sosiologi Volume 2 No. 1, 2013

Kurikulum Dan Pendidikan Di Indonesia:

Proses Mencari Arah Pendidikan Yang Ideal Di Indonesia Atau Hegemoni Kepentingan Penguasa Semata?

Dedi Ilham Perdana

kehidupan berbangsa dan bernegara melalui sektor pendidikan. Karena itu, kurikulum 2013 sesungguhnya bukan kurikulum program kementrian, tetapi kurikulum yang menjadi program pemerintah (Widhi, 2013).

Dari enam perubahan tersebut, tentunya ada muatan kepentingan yang disematkan dalam kurikulum 2013 terkait dengan kepentingan pencitraan karakter bangsa seperu yang diungkapkan oleh Kepala Pusat Komunikasi Publik Kemendikbud, Ibnu Hamad (Widhi, 2013); "dari efek domino itulah maka Kurikulum 2013 adalah bagian tidak terpisahkan untuk menata berbagai aspek kehidupan berbangsa dan bernegara melalui sektor pendidikan. Karena itu, Kurikulum 2013 sesungguhnya bukan kurikulum program kementrian, tetapi kurikulum yang menjadi program pemerintah." Dari pernyataan tersebut tentunya patut kita cermati bahwa ada muatan hegemoni pemerintah terhadap kurikulum 2013.

Dalam kacamata hegemoni Gramsci, fenomena yang terjadi di dunia pendidikan di Indonesia terkait dengan kurikulum 2013, sarat dengan kepentingan kelas penguasa, yakni pemerintah, contohnya Martin Clark mendefinisikan hegemoni sebagai; "cara kelas penguasa mengontrol media dan pendidikan." Sebagaimana dijelaskan diatas, Gramsci mengacu pada hegemoni untuk menggambarkan aktivitas kelompok yang sedang dominan maupun kekuatan-kekuatan progresif (Gramsci, 1971). Rezim pendidikan di Indonesia dalam hal ini mempunyai kekuatan progresif dalam hal kurikulum di kalangan pelajar. Bukti tersebut muncul ketika setiap ada transisi rezim pemerintahan yang berganti seperti perubahan kabinet dan presiden, kurikulum yang ada pun turut berganti materi sehingga memunculkan anomi di dalam wilayah atau bidang pendidikan khususnya pelajar sebagai salah satu instrumen pendidikan di Indonesia.

Bagi Gramsci, apapun kelompok sosialnya kita dapat melihat bahwa terdapat tahapan perkembanganbersama tertentu yang harus mereka lalui sebelum mereka dapat menjadi hegemonik. Mengambil dari Marx, persyaratan pertama adalah ekonomi: bahwa kekuatan material telah cukup dikembangkan sehingga orang-orang didalamnya mampu memecahkan problem-problem sosial yang paling mendesak. Gramsci kemudian berlanjut menyatakan bahwa terdapat tiga tingkat perkembangan politik yang harus dilalui suatu kelompok sosial agar dapat mengembangkan gerakan yang dapat memulai perubahan (Patria, 2009).

Tahap pertama dari ini disebut "korporatekonomis". Seorang korporatis mungkin adalah apa yang kita pahami sebagai individu yang mengutamakan kepentingannya sendiri. Seseorang berafiliasi dengan tahap korporat-ekonomis sebagai fungsi dari kepentingan pribadinya, menyadari bahwa mereka membutuhkan dukungan orang lain untuk memperoleh keamanan mereka sendiri. Sekolah yang melaksankan kurikulum 2013 bisa menjadi contoh dari pengertian ini karena turut mensukseskan kepentingan pemerintah. Dalam istilah ini, kita juga dapat memasukkan kerjasama jangka-pendek antara kapitalis-kapitalis yang sesungguhnya saling berkompetisi satu sama lainnya. Hal yang ditekankan adalah: pada tahap perkembangan historis ini, kelompok yang 
Jurnal Pemikiran Sosiologi Volume 2 No. 1, 2013

Kurikulum Dan Pendidikan Di Indonesia:

Proses Mencari Arah Pendidikan Yang Ideal Di Indonesia Atau Hegemoni Kepentingan Penguasa Semata?

Dedi Ilham Perdana

bersangkutan belum memiliki rasa solidaritas di antara anggota-anggotanya.

Dalam tahap kedua, anggota-anggota kelompok mulai menyadari bahwa terdapat wilayah kepentingan yang lebih luas dan bahwa terdapat orang lain yang berbagi kepentingan dengan mereka dan akan terus membagi kepentingan-kepentingan ini dalam masa depan yang terjangkau. Dalam tahap inilah rasa solidaritas berkembang, tapi hanya berbasiskan kepentingan ekonomi bersama, tidak terdapat pandangan dunia bersama. Solidaritas seperti ini dapat mengarah pada upaya-upaya untuk menggalakkan reformasi-reformasi di bidang hukum untuk memperbaiki posisi kelompok tersebut dalam sistem yang ada, tapi belum ada kesadaran tentang bagaimana mereka, dan yang lainnya, dapat diuntungkan oleh pembentukan sistem yang baru.

Hanya dengan melewati tahap ketiga maka hegemoni dapat terwujud. Dalam tahap ini, anggotaanggota kelompok sosial mulai menyadari kepentingan dan kebutuhan untuk menjangkau melampaui apa yang dapat mereka lakukan dalam konteks kelas-kelas mereka tersendiri. Yang dibutuhkan adalah agar kepentingan mereka turut diusung oleh kelompok-kelompok lainnya yang tersubordinasi seperti halnya mereka. Inilah yang dipikirkan oleh Lenin dan kaum Bolshevik dalam membentuk aliansi dengan kaum tani bahwa hanya dengan membuat revolusi Bolshevik juga menjadi revolusi kaum tani, di mana kaum tani juga melihat itu sebagi revolusi mereka, maka kaum proletariat perkotaan dapat mempertahankan posisi kepemimpinannya. Dalam tiga tahapan tadi, maka dapat dijelaskan motif dasar hegemoni dalam kekuatan progresif penguasa adalah bermuara pada urusan ekonomi. Tak terkecuali di dalam lingkup pendidikan, seperti yang terjadi baru saja di tahun 2013 saja, menurut Wakil Ketua BPK Rizal Djalil (dakwatuna, 2012) menyebutkan bahwa lembaganya menemukan indikasi kerugian negara pada proses pelaksanaan UN 2012 dan 2013 yang besarannya mencapai Rp14 miliar. bisa dipastikan temuan BPK tadi sebagai penanda bahwa ada kepentingan atau motif ekonomi yang terjadi dalam dunia pendidikan yang tentunya yang bertanggung jawab adalah rezim yang saat itu bertugas untuk mengelola bidang pendidikan di Indonesia, muara dari kepentingan ekonomi tersebut adalah hanya untuk kepentingan segelintir pihak. Perihal pergantian kurikulum serta ujian nasional selalu saja terkait dengan alokasi anggaran yang selalu ada dalam setiap jejaknya. Inilah yang menjadi batu pijakan segelintir pihak untuk memanfaatkan posisi di bidang tertentu di instansi pendidikan yang bermain dalam kebijakan anggaran dalam setiap kegiatan pendidikan di Indonesia. Jika kita menelusuri sejarah, kelas kapitalis memegang hegemoninya terutama melalui berbagai bentuk paksaan (koersi), yang berkisar dari penempatan militer secara langsung hingga bentuk-bentuk yang lebih halus, contohnya, menggunakan kekuatan ekonomi untuk menyingkirkan lawan politik (dalam masalah pendidikan tentunya, tetap melanggengkan kurikulum 2013 meskipun ada beberapa elemen yang belum siap melaksanakannya karena sumber daya manusia yang belum memadai). Bagi Pemerintah selaku kelas penguasa, tentunya harus memperhatikan bagaimana kondisi masyarakat Indonesia yang masih rentan terhadap perubahan sosial, khususnya masalah pendidikan, sehingga 
Jurnal Pemikiran Sosiologi Volume 2 No. 1, 2013

Kurikulum Dan Pendidikan Di Indonesia:

Proses Mencari Arah Pendidikan Yang Ideal Di Indonesia Atau Hegemoni Kepentingan Penguasa Semata?

Dedi Ilham Perdana

diharapkan arah pendidikan nasional bukan hanya rencana kabinet seumur jagung, tapi juga masalah keberlangsungan pendidikan, karena porsi jabatan politik sangat berbeda dengan dunia pendidikan, apabila posisi jabatan politik selama lima tahun, tentunya dunia pendidikan tidak hanya berkisar pada hitungan angka tersebut, pastinya harus ada upaya untuk menjembatani segala macam ide yang datang dari masyarakat guna mencegah adanya pertentangan dari masyarakat tentang pendidikan.

\section{E. Kesimpulan}

Melihat banyak sekali problematika dalam pendidikan, kiranya kita dapat melihat proses peneidikan hanya di monopoli oleh pemerintah yang berkuasa, tanpa ada upaya melibatkan pihak luar seperti organisasi non profit atau LSM bahkan pihak-pihak yang konsisten di dunia pendidikan Indonesia. Pemerintah merasa mumpuni untuk meraih prestasi terbaik hanya dengan dominasi kurikulum yang tanpa disadari tiap pindah orde selalu berganti sehingga menimbulkan anomali dalam tubuh pendidikan itu sendiri. dominasi tanpa batas itu lantas merajut kepada pihak konglomerasi yang ingin memanfaatkan situasi tersebut demi meraup keuntungan dengan mengirbankan pelaku pendidikan yang menjadi korban atas berubahubahnya sistem kebijakan yang ada.

Menjadi suatu yang lazim, apabila banyak sekali kesalahan dalam model pendidikan maka yang patut disalahkan adalah sisea yang menjadi siklus korban terakhir dari rezim pendidikan yang ada di Indonesia. padahal nyata dan jelas bahwa pemerintah Indonesia yang berkewajiban atas semua arah kebijakan pendidikan di Indonesia.

Dalam hal dominasi pendidikan di Indonesia, pemerintah hanya berusaha menghegomoni dari sisi motif ekonomi saja, lewat usaha pengadaan barang dan jasa dalam kegiatan pendidikan, sehingga memunculkan pemborosan anggaran seperti pada pengadaan soal ujian nasional namun tak sejalan dengan prestasi yang ada. Fenomena tersebut seringkali diabaikan oleh pemerintah yang jelas punya ansil besar dalam kemunduran dunia pendidikan di Indonesia.

Ketidakberimbangan situasi tersebut merupakan proses hegemoni panjang dari penerintah atas pendidikan di Indonesia. melihat kenyataan seperti itu, menjadi lebih bijak untuk semua pelaku pendidikan di Indonesia khususnya pemerintah berusaha untuk menyamakan persepsi dengan semua elemen masyarakat Indonesia agar dominasi pemerintah atas pendidikan dapat diawasi dan diperbaiki guna menuju iklim pendidikan ideal bagi masyarakat di Indonesia dan bukan lagi sebuah hegemoni atas nama motif ekonomi semata.

\section{Daftar Pustaka}

Mulder, Niels. 2007. Wacana Publik Indonesia. Kanisius

Nasution, S. 2008. Kurikulum dan Pengajaran. Bumi Aksara.

Nuryatno, M. Agus. 2008. Mazhab Pendidikan Kritis. Resist Book.

Patria, Nezar. 2009. Antonio Gramsci: Negara dan Hegemoni. Pustaka Pelajar

Allen, John. 2006. Negara Memahami Pendidikan. Trimedia

Prasetyo, Eko. 2006. Guru: Mendidik Itu Melawan!. Resist Book. 
Jurnal Pemikiran Sosiologi Volume 2 No. 1, 2013

Kurikulum Dan Pendidikan Di Indonesia:

Proses Mencari Arah Pendidikan Yang Ideal Di Indonesia Atau Hegemoni Kepentingan Penguasa Semata?

Dedi Ilham Perdana

Print, Murray. 1993. Curriculum Development And Design. Allen \& Unwin.

Clark, M. (1977). Antonio Gramsci and the Revolution that Failed. New Haven: Yale University Press.

Gramsci, Antonio. 1971. Selections from The Prison Notebooks of Antonio Gramsci, Q. Hoare \& G. N. Smith, eds. \& trans. London: Lawrence and Wishart

\section{Sumber lain (berita online/internet):}

http://news.detik.com/read/2013/07/14/162017 /2302125/10/2/6-perubahan-pada-kurikulum2013-dibanding-kurikulum-lama

http://www.metrotvnews.com/metronews/read/2 013/07/11/3/167491/Ada-Sejumlah-Masalah-

Krusial-dalam-Implementasi-Kurikulum-2013

http://nasional.sindonews.com/read/2013/05/08 /15/746348/budaya-ganti-menteri-gantikurikulum-harus-dihilangkan

http://edukasi.kompas.com/read/2013/02/16/08 383096/Kurikulum.2013..Beban.Baru.Siswa.dan.Gu $\mathrm{ru}$

http://www.jpnn.com/read/2013/07/09/180861/ Federasi-Guru-Kritik-Persiapan-Hadapi-

Kurikulum-2013-

http://www.antaranews.com/berita/385504/kuri kulum-2013-diterapkan-secara-bertahap

http://www.tempo.co/read/news/2013/09/27/07 9517076/Tolak-UN-Koalisi-Tinggalkan-Konvensi

http://www.dakwatuna.com/2013/09/26/39833/ surahman-usut-tuntas-dugaan-korupsi penyelenggaraan-un-2012-dan-

2013/\#ixzz2jnCoy3H3 